\title{
New cytostatics-more activity and less toxicity
}

\author{
Martin R. Berger, Heike Richter, Matthias H. Seelig, Hansjörg Eibl* and \\ Dietrich Schmähl
}

Institute of Toxicology and Chemotherapy, German Cancer Research Center, 6900 Heidelberg, and * Max Planck Institute of Biophysical Chemistry, 3400 Göttingen, FRG

\section{Introduction}

A main task of experimental antineoplastic chemotherapy is to identify new active lead structures and, subsequently, to investigate structure activity-relationships in order to find congeners with an increased therapeutic ratio.

Unfortunately, to date no rational approach has been developed that allows reliable identification of structures active against the most common solid human neoplasms such as lung, breast and colorectal cancer $(2,11,18)$. It is therefore not surprising that the majority of classes of anticancer agents in clinical use has originally been identified by chance, while subsequent experiments on structure-activity relationships were performed according to all available knowledge on systematic chemical variations.

During the last decade, the approach of our group to identify and characterize new anticancer agents has been based on the use of transplanted as well as chemically induced autochthonous tumors (2l). The latter models show closer similarity to the respective human neoplasias compared to transplanted tumors and may therefore permit a more precise prediction of anticancer activity in man to be made $(21,24)$.

Methylnitrosourea (MNU)-induced rat mammary carcinoma and acetoxymethylmethylnitrosamine (AMMN)-induced colorectal carcinoma of the rat have specifically been chosen for advanced drug evaluation since they represent two important types of human cancer both of which need more successful treatment by new antineoplastic agents $(13,20)$. This system enabled the identification of two new key structures, namely dinaline [4-amino-N-(2'-aminophenyl)benzamide, (GOE1734)] and miltefosine [hexadecylphosphocholine ( $\mathrm{HePC})]$ that would have been missed if the customary transplanted tumor models only had been used $(7,10)$. In this article we report on experiments performed to establish structure activity relationships on these two new compounds.

\section{Material and methods}

\section{Chemicals}

Dinaline, p-N-acetyl-dinaline (GOE5549) and p-N-methyldinaline (GOE4902, see Figure 1) were supplied by Goedecke AG (Freiburg, FRG) in a quality sufficient for clinical use; 


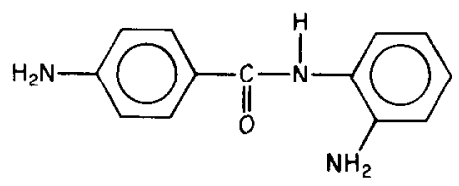

Dinaline (GOE 1734)

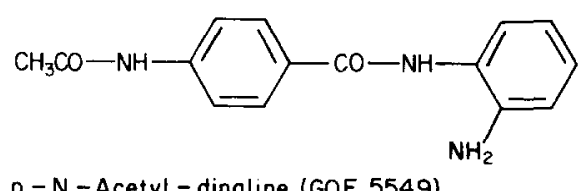

$p-N-A c e t y l-d i n a l i n e(G O E 5549$ )

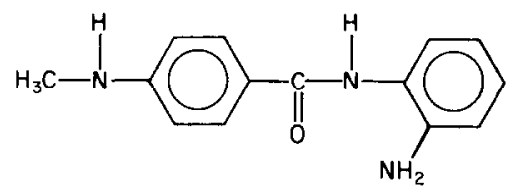

$p-N-$ Methyl - dinaline (GOE 4902)

Figure 1. Chemical structures of dinaline [4-amino- $\mathrm{N}$ - $\left(2^{\prime}\right.$-aminophenyl) benzamide, GOE 1734], p-N-acetyldinaline (GOE 5549) and p-N-methyl-dinaline (GOE 4902).

for experimental purposes they were suspended in $0.8 \%$ methocel (Nordmann-Rasmann, Hamburg, FRG) at a concentration of $6 \mathrm{mg} / \mathrm{ml}$.

Miltefosine was supplied by Asta Pharma (Frankfurt, FRG) and ilmofosine (1-hexadecylmercapto-2-methoxymethyl-rac-propyl-3-phosphocholine, TLP) by Boehringer Mannheim (Mannheim, FRG). Octadecylphosphocholine (18:0-PG), octadecenyl-(trans9.10)-phosphocholine (t-18:1-PC) and octadecenyl-(cis-9.10)-phosphocholine (c-18:1-PC; see Figure 2) were synthesized according to published methods.<smiles>CCCOP(=O)([O-])OCC[N+](C)(C)C</smiles>

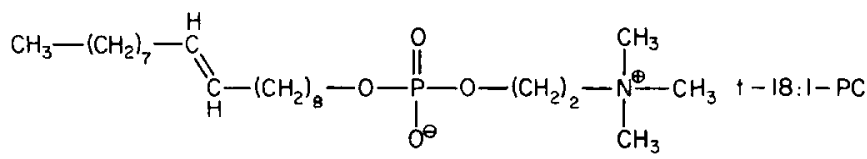<smiles>CCCCCOP(=O)([O-])OCC[N+](C)(C)C</smiles>

Figure 2. Chemical structures of octadecylphosphocholine (18:0-PC), octadecenyl-(trans-9.10)-phosphocholine (t-18:1-PC) and octadecenyl-(cis-9.10)-phosphocholine (c-18:1-PG). 
Miltefosine and ilmofosine were of a quality sufficient for clinical use, the other alkylphospholipids were checked for purity by TLC and elemental analysis. Ilmofosine and all alkylphospholipids were dissolved in water at appropriate concentrations immediately before use.

MNU and AMMN were synthesized by Dr M. Wiessler (Institute of Toxicology and Chemotherapy, German Cancer Research Center, Heidelberg, FRG) and dissolved at $1 \%$ and $0.2 \%$ shortly before use.

\section{Animals and tumor induction}

Rats were purchased from commercial sources (Zentralinstitut für Versuchstierzucht, Hannover, FRG, and Charles River Breeding, Sulzfeld, FRG) and maintained under conventional conditions (temperature $22^{\circ} \pm 2^{\circ} \mathrm{C}$, relative humidity $55 \% \pm 10 \%$; darklight rhythm of $12 \mathrm{~h}$ ). Altromin pellets and water were given ad lib.

Autoch thonous, hormone-dependent mammary carcinomas were induced by MNU in female SD rats as described previously (5). Rats with a total tumor volume $>0.8 \mathrm{~cm}^{3}$ were randomly allocated to experimental groups, therapy started immediately thereafter for a period of five weeks. Induction of autochthonous, colorectal adenocarcinomas with AMMN in male SD rats was performed over 10 weeks, as previously described (8). Animals with endoscopically evident tumors were randomly allocated to treatment and control groups. Treatment started immediately thereafter and was continued for 10 weeks.

\section{Evaluation of antitumor activity}

The tumor volume in treated and untreated rats was determined at regular intervals (MNU-model) or at the end of therapy $(\Lambda \mathrm{MMN}$-model). The median volumes of groups were expressed in per cent of untreated controls $(\mathrm{T} / \mathrm{C} \times 100)$. Alternatively, the increase in tumor growth determined as a quotient of final minus initial median tumor volumes was used for comparison of treated and untreated groups. Complete remissions of all tumor lesions were assessed separately and expressed in per cent of animals per group.

\section{Results}

The anticancer efficacy of the thioether alkyllysophospholipid ilmofosine in MNU-induced rat mammary carcinoma is shown in Tables 1 and 2 and Figure 3. Regular administration of $40 \mathrm{mg} / \mathrm{kg}$ reproducibly caused tumor growth inhibition exceeding $95 \%$ and complete remissions in one-third of the animals concomitantly with an arrest of body weight development and a mortality rate comparable to that of untreated controls (group 3 and 6, Table 1). Dose-response relationships with doses scaled up or down by factor 1.5 , however, showed a relatively narrow therapeutic ratio since a higher dose $(60 \mathrm{mg} / \mathrm{kg}$ group 2, Table 1) was associated with unacceptable toxicity and lower doses $(27 \mathrm{mg} / \mathrm{kg}$ groups 4 and $7 ; 18 \mathrm{mg} / \mathrm{kg}$, group 8 , Table 1) were only marginally effective. Interestingly, the optimal dose of ilmofosine was equally effective in intact as well as ovariectomized tumor-bearing rats, as shown in Table 1 (groups 9-11) and Figure 3(B) effecting more than $95 \%$ tumor growth inhibition following ovariectomy. The influence of pulse doses of ilmofosine (Table 2) was comparable to that of regular administration, provided the time 


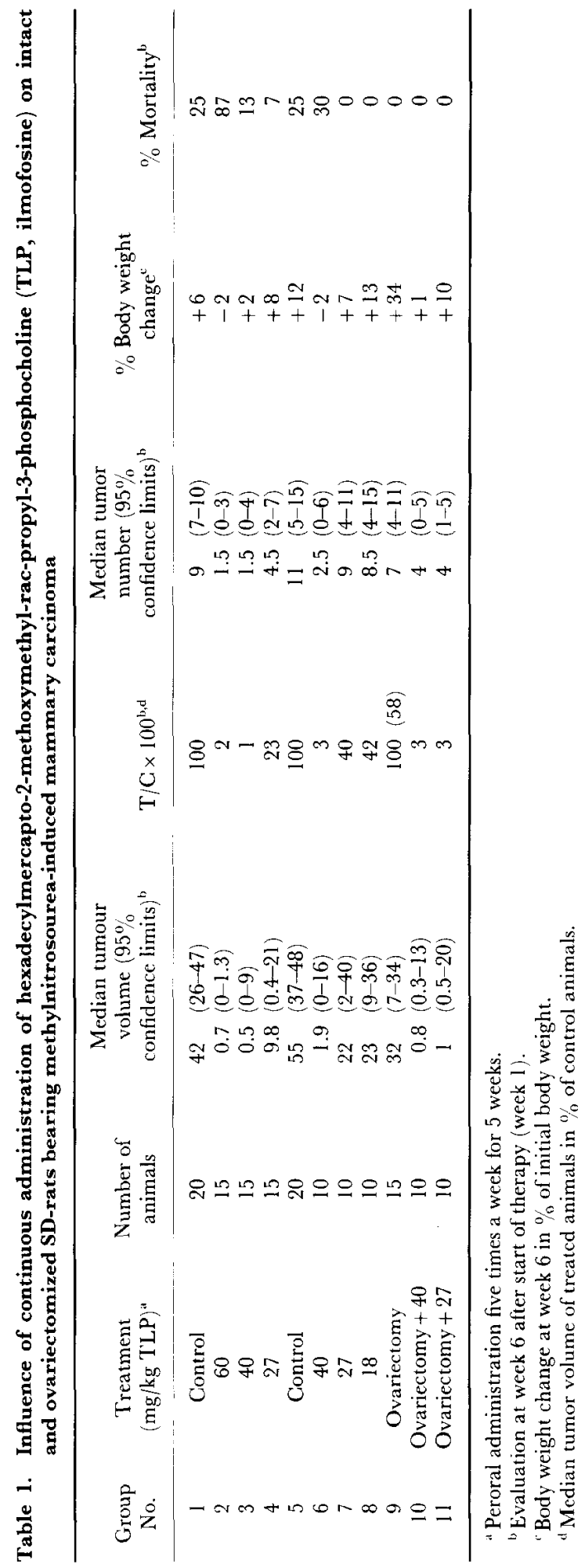




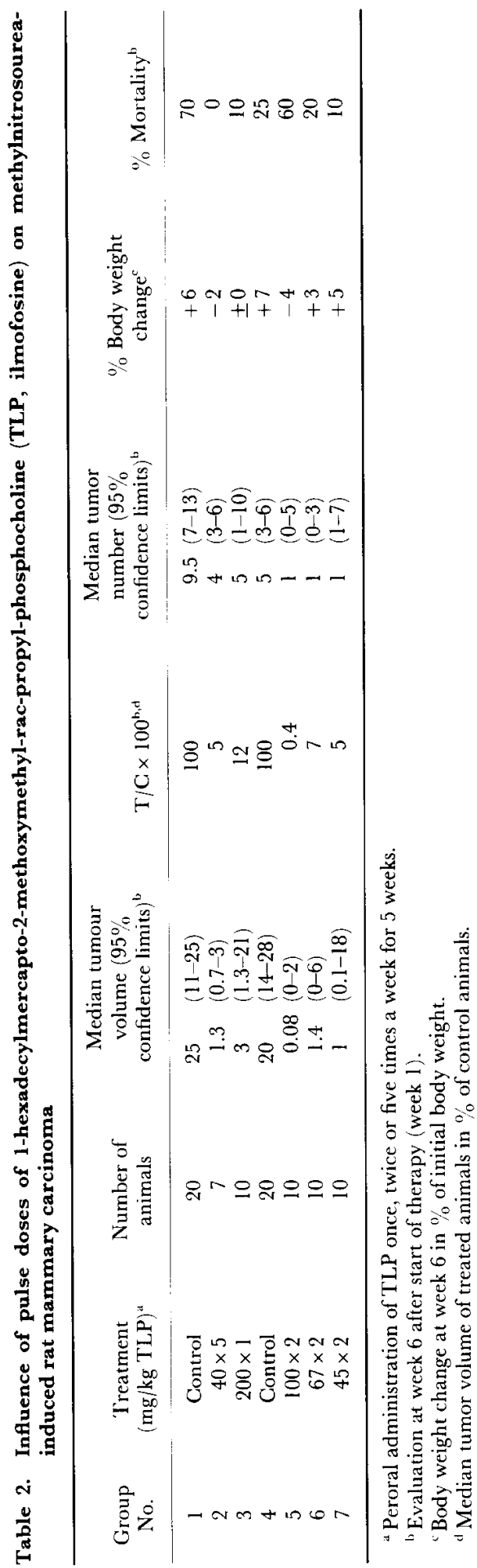




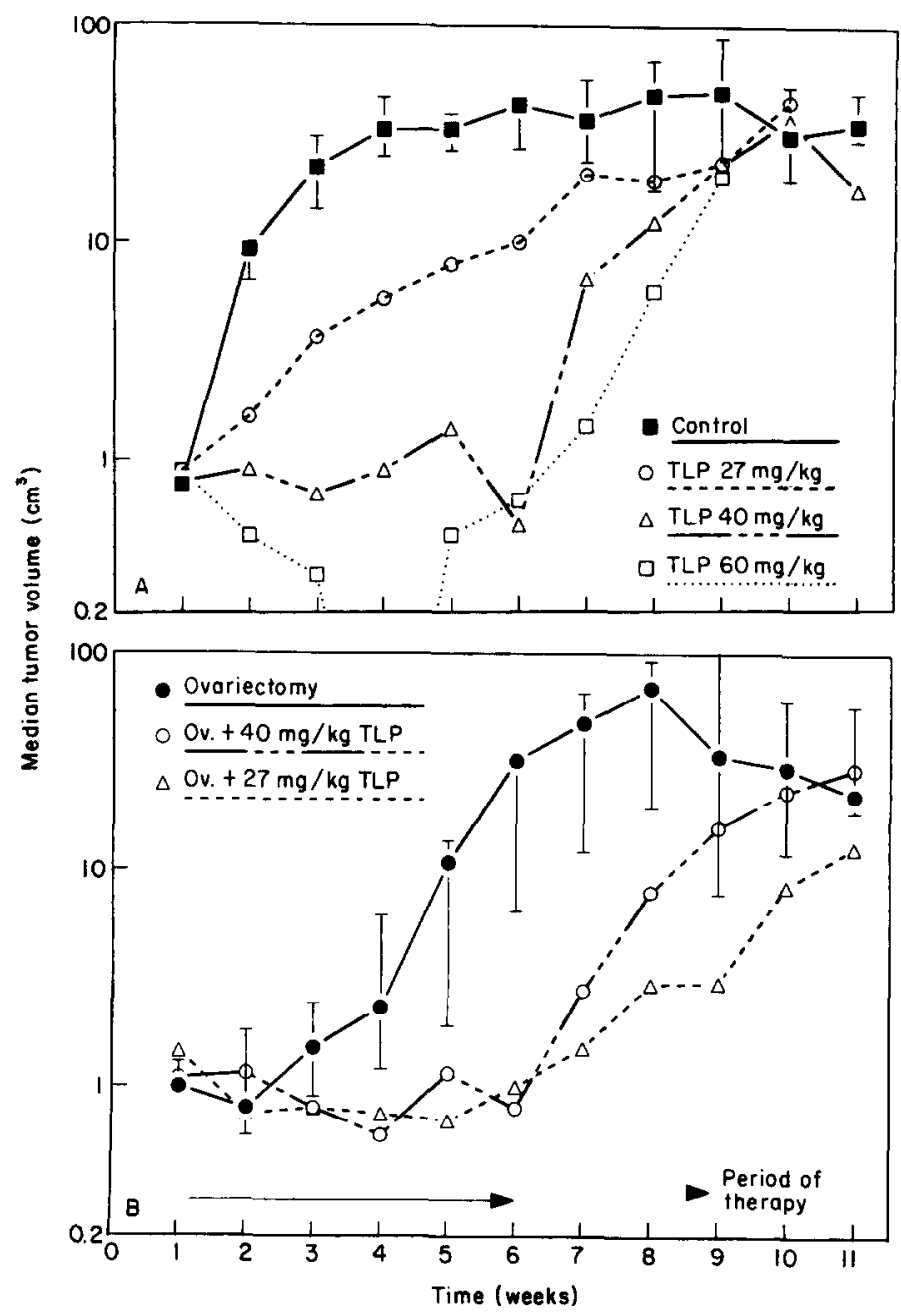

Figure 3. Influence of ilmofosine (TLP) on the growth of methylnitrosourea-induced rat mammary carcinoma in intact (A: $\mathbf{1}$, control; O, TLP $27 \mathrm{mg} / \mathrm{kg} ; \triangle$, TLP $40 \mathrm{mg} / \mathrm{kg} ; \square, 1 \mathrm{LP} 60 \mathrm{mg} / \mathrm{kg}$ ) and ovariectomized SDrats (B: O, ovariectomy; O, ovariectomy + TLP $40 \mathrm{mg} / \mathrm{kg} ; \triangle$, ovariectomy + TLP $27 \mathrm{mg} / \mathrm{kg}$ ).

interval was less than 4 days. This is evidenced by the fact that five administrations of 40 $\mathrm{mg} / \mathrm{kg}$ ilmofosine, corresponding to a total optimal dose per week of $200 \mathrm{mg} / \mathrm{kg}$ were more effective than a single dose of $200 \mathrm{mg} / \mathrm{kg}$ per week (groups 2 and 3, Table 2), but similarly effective as two doses of $100 \mathrm{mg} / \mathrm{kg}$ per week (group 5, Table 2).

Rerrarkably, this administration schedule was also associated with high anticancer activity at lower total dosages (groups 6 and 7, Table 2), which were less effective when given by five administrations per week.

The influence of weekly pulse doses of the alkylphosphocholine miltefosine on rats bearing MNU-induced mammary carcinomas is depicted in Table 3 and Figure 4. This schedule of miltefosine reproducibly exerted high anticancer activity over the dose range tested, with an optimal dose of $150 \mathrm{mg} / \mathrm{kg} /$ wock (groups 2 and 6 , Table 4 ) that effected 


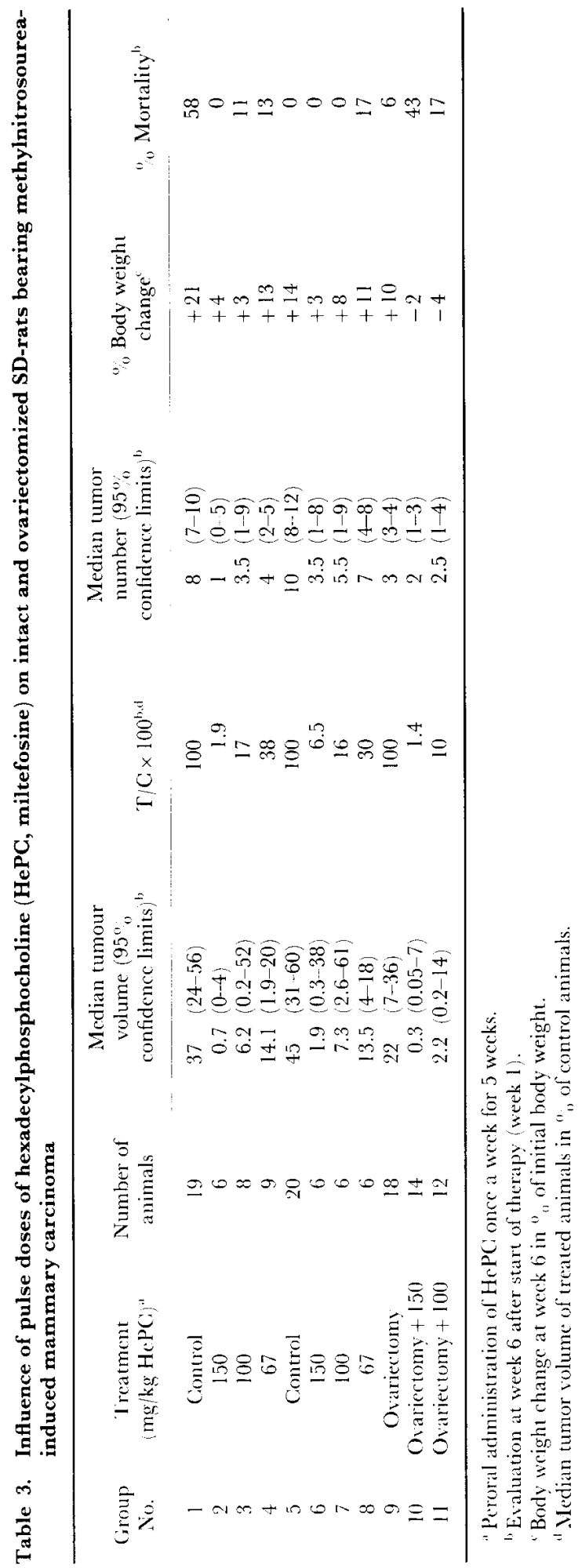




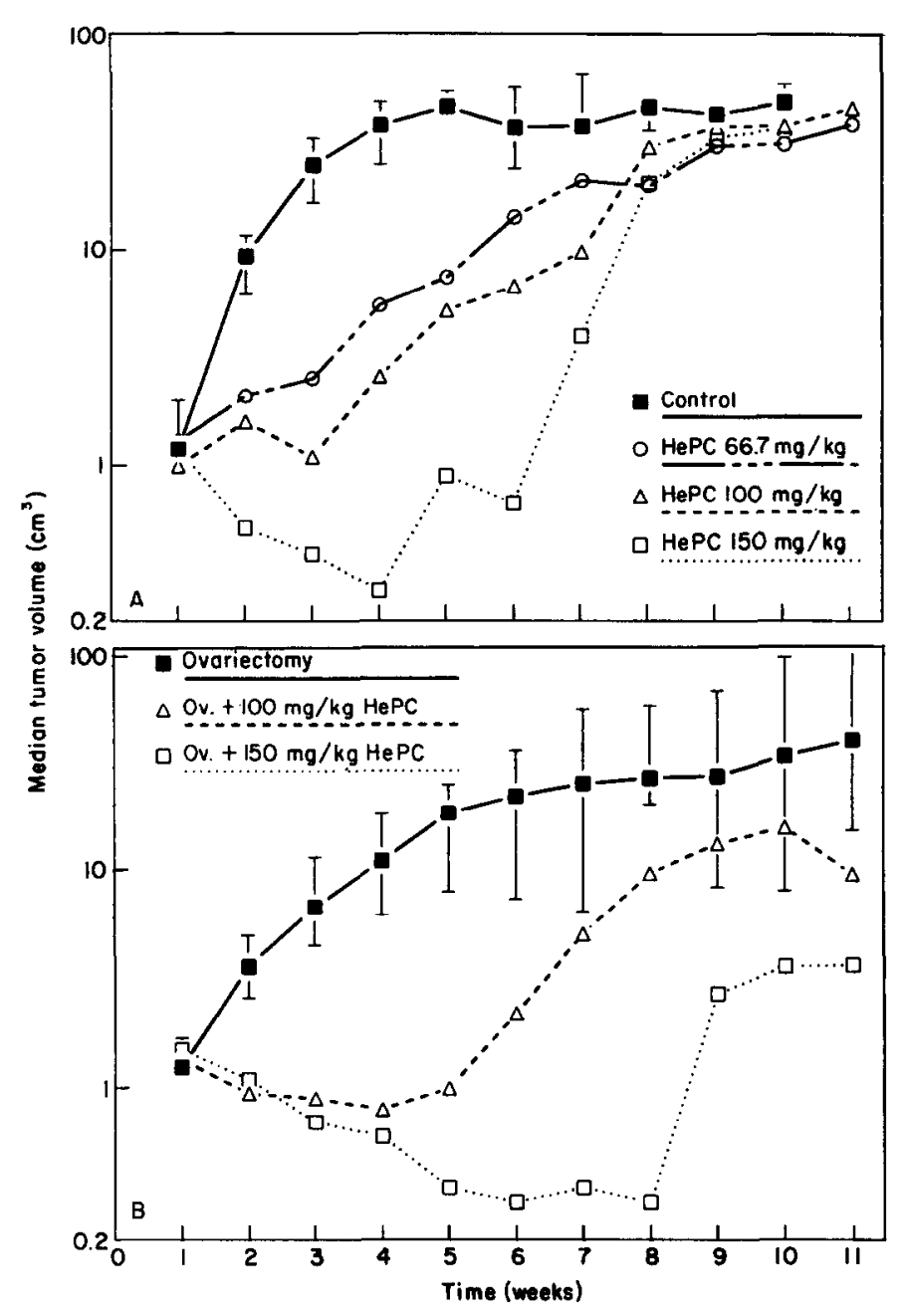

Figure 4. Influence of miltefosine (HePC) on the growth of methylnitrosourea-induced rat mammary carcinoma in intact (A: $\mathbf{\square}$, control; O, HePC $66.7 \mathrm{mg} / \mathrm{kg} ; \triangle, \mathrm{HePc} 100 \mathrm{mg} / \mathrm{kg} ; \square, \mathrm{HePC} 150 \mathrm{mg} / \mathrm{kg}$ ) and ovariectomized SD-rats (B: $\square$, ovariectomy; $\triangle$, ovariectomy + HePC $100 \mathrm{mg} / \mathrm{kg}$; $\square$, ovariectomy + HePC $150 \mathrm{mg} / \mathrm{kg}$ ).

$30 \%$ complete remissions. Comparable to the effectiveness in mammary lesions of intact rats, miltefosine also reduced the median tumor volume of ovariectomized animals to less than $50 \%$ of its original size [group 10, Table 4 and Fig. $4(\mathrm{~B})$ ]. According to a straight dose response relationship the lower doses of miltefosine $(100 \mathrm{mg} / \mathrm{kg}$ : groups $3,7,11$; and $67 \mathrm{mg} / \mathrm{kg}$ : groups 4, 8; Table 4) were less effective than the highest, optimal dose.

The antitumor activity of three newly synthesized alkylphosphocholines as well as that of three N-acyl-O-phenylenediamine derivatives is given in Table 4. Octadecylphosphocholine, administered at doses of 65 and $130 \mathrm{mg} / \mathrm{kg} /$ week, arrested the growth of mammary carcinomas completely at the lower dose and caused considerable mortality at the higher dose. The monounsaturated congeners t-18:1-PC and c-18:1-PC were less toxic, demonstrating an increase in the maximal tolerable dose by a factor of 
Table 4. Anticancer activity of alkylphosphocholines and N-acyl-O-phenylenediamines in methylnitrosourea-induced rat mammary carcinoma

\begin{tabular}{|c|c|c|c|c|}
\hline Treatment" & $\begin{array}{l}\text { Dosage } \\
(\mathrm{mg} / \mathrm{kg})^{\mathrm{b}}\end{array}$ & $\%$ Mortality & $\begin{array}{l}\text { Tumor } \\
\text { growthe }\end{array}$ & $\begin{array}{l}\text { \% Complete } \\
\text { remissions }\end{array}$ \\
\hline Control & $\cdots$ & 20 & 27-fold increase & 0 \\
\hline \multirow[t]{2}{*}{$18: 0-\mathrm{PC}$} & 13 & 20 & Arrest & 0 \\
\hline & 26 & 40 & Regression & 0 \\
\hline \multirow[t]{3}{*}{$\mathrm{t}-18: 1-\mathrm{PC}$} & 13 & 0 & Arrest & 10 \\
\hline & 26 & 0 & Regression & 30 \\
\hline & 52 & 100 & $\ldots$ & $-\cdots$ \\
\hline \multirow[t]{3}{*}{$c-18: 1-\mathrm{PC}$} & 13 & 0 & Arrest & 0 \\
\hline & 26 & 0 & Regression & 20 \\
\hline & 52 & 20 & Regression & 60 \\
\hline Control & - & 35 & 27-fold increase & 0 \\
\hline \multirow[t]{2}{*}{ Dinaline } & 7.5 & 0 & Twofold increase & 0 \\
\hline & 10 & 10 & Twofold increase & 20 \\
\hline p-N-Acetyl-dinaline & 8.9 & 10 & Arrest & 0 \\
\hline \multirow{4}{*}{ p-N-Methyl-dinaline } & 8.0 & 0 & Tenfold increase & 0 \\
\hline & 10.6 & 10 & Twofold increase & 10 \\
\hline & 13.3 & 0 & Threefold increase & 10 \\
\hline & 17.6 & 80 & $\ldots$ & - \\
\hline
\end{tabular}

${ }^{4}$ Start of treatment after a median tumor volume of $1 \mathrm{~cm}^{3}$ had been reached (week 1 ).

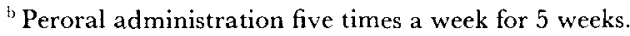

"Assessment at the end of treatment (week 6).

two for the former and a factor of four for the latter compound. Concomitantly, increased antitumor efficacy was observed with lower toxicity as shown by the percentages of animals with complete remission: $0 \%$ following 18:0-PC, 30\% following $\mathrm{t}-18: 1-\mathrm{PC}$ and $60 \%$ following c-18: 1-PC (Table 4).

Regular administration of dinaline, $\mathrm{p}-\mathrm{N}$-acetyl-dinaline and $\mathrm{p}-\mathrm{N}$-methyl-dinaline to rats bearing MNU-induced mammary carcinoma (Table 4) effected comparably high antitumor efficacy with more than $90 \%$ tumor growth inhibition at optimal doses. Dinaline and its p-N-methyl-congener also effected complete remissions in $10 \%-20 \%$ of animals treated with optimal dosages. Regarding this efficacy, the new $\mathrm{p}-\mathrm{N}$-methyl derivative showed a somewhat higher therapeutic ratio in this model compared to dinaline. The antineoplastic potential of these derivatives was determined in AMMN-induced colorectal carcinoma, as well (Table 5). At dosages causing mortality not exceeding that of untreated controls dinaline and $\mathrm{p}-\mathrm{N}$-acetyl-dinaline arrested the growth of colorectal adenocarcinomas completely, but $\mathrm{p}-\mathrm{N}$-methyl-dinaline caused regression of the median tumor volume. In addition, administration of the latter derivative was associated with a dose dependent induction of complete remissions $(27,20,7$ and $0 \%$ at the four dosages used, respectively).

\section{Discussion}

Alkyllysophospholipids and alkylphosphocholines represent two related classes of anticancer agents that target the cell membrane $(4,12,19)$. Selective sensitivity of chemically induced, autochthonous mammary carcinoma to these agents has been established recently $(6,10,16)$. This sensitivity might be due to several reasons including the finding that MNU- and 7,12-dimethylbenzanthracene-induced rat mammary carcinomas are known 
Table 5. Anticancer efficacy of $\mathrm{N}$-acyl-o-phenylenediamines in acetoxymethylmethylnitrosamine-induced colorectal cancer of SD rats

\begin{tabular}{lcccc}
\hline Treatment & $\begin{array}{c}\text { Dosage } \\
(\mathrm{mg} / \mathrm{kg})^{\mathrm{b}}\end{array}$ & \% Mortality & $\begin{array}{c}\text { Tumor } \\
\text { growth }\end{array}$ & $\begin{array}{c}\text { \% Complete } \\
\text { remissions }\end{array}$ \\
\hline Control & - & 15 & Tenfold increase & 0 \\
Dinaline & 10.0 & 87 & Regression & 20 \\
& 7.7 & 47 & Arrest & 0 \\
p-N-Acetyl-dinaline & 5.9 & 13 & Arrest & 7 \\
& 11.9 & 80 & Regression & 0 \\
& 9.1 & 20 & Arrest & 0 \\
p-N-Methyl-dinaline & 7.0 & 13 & Arrest & 0 \\
& 5.3 & 20 & Twofold increase & 0 \\
& 13.8 & 27 & Regression & 27 \\
& 10.6 & 27 & Regression & 20 \\
\end{tabular}

\footnotetext{
${ }^{a}$ Start of treatment after a median tumor volume of $50 \mathrm{~mm}^{3}$ had been reached.

${ }^{\text {b }}$ Peroral administration five times a week for 10 weeks.

"Assessment following a 10 week treatment period.
}

to contain a mutated $c \mathrm{H}$-ras oncogene resulting in the expression of an altered G-protein which is located in the membrane and involved in signal transduction (3). Interference with cellular signal pathways that may be over- or inappropriately expressed in cancerous cells is a plausible assumption of the mechanism of action of these agents. A further characteristic of these tumors which contain measurable levels of estradiol, progesterone, and androgen receptors is their sensitivity to hormones, antihormones and hormone-linked agents $(1,9)$. Discrimination between these two modes of sensitivity can be shown by treating tumors which grow hormone-independently in ovariectomized animals. Since both ilmofosinc and miltcfosinc cxert cquivalent anticancer activity in mammary carcinomas of intact and ovariectomized animals, a hormone-independent mechanism of action of these two classes of agents can be assumed.

The equivalent efficacy of both ether lipids following regular, repeated administration and one or two pulse doses per week is in line with data on serum kinetics of ilmofosine and miltefosine, indicating half-lives of $30 \mathrm{~h}$ and $96 \mathrm{~h}$ for the two agents $(15,22)$. The more than twice as long half-life in favor of miltefosine and its simpler administration schedule justify its selection for clinical studies as compared to related agents that are more potent in vitro (23). With regard to second generation alkylphosphocholines that show increased therapeutic ratio, such as c-18:1-PG, it is interesting to note that only a small chemical modification (introduction of a cis-configurated double bond into the fatty acid chain) is responsible for considerably increased activity and lowered toxicity as compared to 18:0-PC. Despite their superior activity in chemically induced mammary carcinoma alkyllysophospholipids and alkylphosphocholines show a very narrow spectrum of activity.

$\mathrm{N}$-acyl-O-phenylenediamines, such as dinaline, also have a selective but somewhat broader spectrum of tumor models in which activity has been demonstrated $(7,14,17)$. Dinaline so far was the only drug with remarkable activity in both the MNU- and AMMN-induced tumor systems. The increased therapeutic ratio of the $\mathrm{p}-\mathrm{N}$-methyl derivative probably reflects metabolic conversion, since dinaline is rapidly acetylated to $\mathrm{p}-\mathrm{N}$ acetyl-dinaline in liver cells whereas $\mathrm{p}-\mathrm{N}$-methyl-dinaline first requires $\mathrm{N}$-demethylation before $\mathrm{N}$-acetylation can take place. By this mechanism sustained levels of active metabolites might be available that bring about increased antitumor activity in $\triangle \mathrm{MMN}$-induced 
colorectal carcinoma including a considerable number of complete remissions-an observation that had never been made before in this model, neither with clinically used nor experimental drugs--and which confer reduced toxicity at equimolar dosages.

It is to be hoped that both classes of agents will be followed up successfully in clinical studies and will contribute to an improved outcome of treating the most common solid tumors in man.

\section{Conclusion}

Pulse doses and regular administration of the thioether alkyllysphospholipid ilmofosine and the alkylphosphocholine miltcfosine exerted equally high antineoplastic activity in intact and ovariectomized rats bearing primary methylnitrosourea-(MNU) induced mammary carcinoma. Introduction of a cis- or trans-configurated double bond into the fatty acid moiety of octadecylphosphocholine-an alkylphosphocholine analog which shows anticancer efficacy comparable to miltefosine-generated compounds with distinctly increased therapeutic ratio thus inducing complete remission in up to $60 \%$ of treated mammary carcinoma bearing rats. In contrast to the selective activity of alkyllysophospholipids and alkylphosphocholines, the new N-acyl-O-phenylenediamine derivative $\mathrm{p}-\mathrm{N}$-methyl-dinaline effected not only equivalently high anticancer activity in MNUinduced mammary carcinomas, but also tumor regressions including complete remissions in up to $26 \%$ of animals in autochthonous, acetoxymethylmethylnitrosamine-induced colorectal rat carcinoma.

\section{Acknowledgements}

The skilful technical assistance of Mr H. Grage, Mr H. Opitz and Ms K. Bültmann is gratefully acknowledged.

\section{References}

1. Angerer, E. v., Prekajac, J. \& Berger, M. R. (1985) The inhibitory effect of 5-acetoxy-2-(4-acetoxyphenyl)1-ethyl-3-methylindole (D 16726) on estrogen-dependent mammary tumors. Europ. J. Cancer Clin. Oncol. 21: $531-537$.

2. Atassi, G. (1984) Do we need new chemosensitive experimental models? Europ. J. Cancer Clin. Oncol. 20: $1217-1220$.

3. Barbacid, M. (1986) The role of ras oncogenes in neoplastic development. In: Fortner, J. G., Rhoads, J. E., eds. Accomplishments in Cancer Research 1985. Philadelphia: Lippincott Company, pp. 179-187.

4. Berdel, W. E., Andreesen, R. \& Munder, P. G. (1985) Synthetic alkyl-phospholipid analogs; a new class of antitumor agents. In: Kuo, J. F., ed. Phospholipids and Cellular Regulation, Volume 2. Boca Raton: CRC Press, pp. $41-73$.

5. Berger, M. R., Habs, M. \& Schmähl, D. (1983) Noncarcinogenic chemotherapy with a combination of vincristine, methotrexate and 5-fuorouracil (VMF) in rats. Int. J. Cancer 32: 231-236.

6. Berger, M. R., Munder, P. G., Schmähl, D. \& Westphal, O. (1984) Influence of the alkyllysophospholipid $\mathrm{ET}-18-\mathrm{OCH}_{3}$ on methylnitrosourea-induced rat mammary carcinomas. Oncology 41: 109-113.

7. Berger, M. R., Bischoff, H., Fritschi, E., Henne, T., Hermann, M., Pool, B. L., Satzinger, G., Schmähl, D. \& Weiershausen U. (1985) Synthesis, toxicity and therapeutic efficacy of 4-amino- $\mathrm{N}-\left(2^{\prime}\right.$-aminophenyl $)$ - 
benzamide: A new compound preferentially active in slowly growing tumors. Cancer Treat. Rep. 69: 14151424.

8. Berger, M. R., Bischoff, H., Garzon, F. T. \& Schmähl, D. (1986) Autochthonous, acetoxymethylmethylnitrosamine-induced colorectal cancer in rats: A useful tool in selecting new active antineoplastic compounds? Hepato-gastroenterol 33: 227-234.

y. Berger, M. K., Floride, J., Schmähl, D., Schreiber, J. \& Eisenbrand, G. (1986) Estrogen-linked 2-chloroethylnitrosoureas: anticancer efficacy in MNU-induced rat mammary carcinoma, uterine activity in mice and receptor interactions. Europ. J. Cancer Clin. Oncol. 22: 1179-1191.

10. Berger, M. K., Muschiol, C., Schmähl, D. \& Eibl, H. J. (1987) New cytostatics with experimentally different toxic profiles. Cancer Treat. Rev. 14: 307-317.

11. Corbett, T. H., Valeriote, F. A. \& Baker, L. H. (1987) Is the P388 murine tumor no longer adequate as a drug discovery model? Invest. New Drugs 5: 3-20.

12. Eibl, H. \& Unger, C. (1987) Phospholipide als Antitumormittel: Möglichkeiten einer selektiven Therapie. In: Unger, C. et al. (ed): Die Zellmembran als Angriffspunkt der Tumortherapie. Zuckerschwerdt, München. Aktuelle Onkologie 34: 1-18.

13. Galeano, A., Petru, E., Berger, M. R. \& Schmähl, D. (1990) Use of various cytotoxic regimens in the palliative treatment of colon cancer. Tumor Diagn. Ther. 11: 104-110.

14. Hagenbeek, A., Weiershausen, U. \& Martens, A. C. M. (1988) Dinaline: A new oral drug against leukemia? Preclinical studies in a relevant rat model for human acute myelocytic leukemia (BNML). Leukemia 2: 226230.

15. Herrmann, D. B. J., Besenfelder, E., Bicker, U., Pahlke, W. \& Böhm, E. (1987) Pharmacokinetics of the thioether phospholipid analogue BM 41.440 in rats. Lipids 22: 952-954.

16. Hilgard, P., Stekar, J., Voegeli, R., Engel, J., Schuhmacher, W., Eibl, H., Unger, C. \& Berger, M. R. (1988) Characterization of the antitumor activity of hexadecylphosphocholine (D18506). Europ. J. Cancer Clin Oncol, 24: 1457-1467.

17. Lelieveld, P., Middeldorp, R. J. F. \& Putten, L. M. van (1985) Effectiveness of p-aminobenoyl-O-phenylenediamine (Goe 1734) against mouse, rat, and human tumor cells. Cancer Chemother. Pharmacol. 15: 88-90.

18. Martin D. S., Balis, M. E., Fisher, B., Frci, E., Freireich, E. J., Heppner, G. H., Holland, J. F., Houghton, J. A., Houghton, P. I., Johnson, R. K., Mittelman, A., Rustum, Y., Sawyer, R. C., Schmid, F. A., Stolf, R. L. \& Young, C. W. (1986) Role of murine tumor models in cancer treatment research. Cancer Res. 46: 2189-2192.

19. Munder, P. G., Modolell, M., Bausert, W., Oettgen, H. F. \& Westphal, O. (1981) Alkyllysophospholipids in cancer therapy. In: Hersh, E. M. et al., eds. Augmenting Agents in Cancer Therapy. New York: Raven Press, 441-458

20. Petru, E. \& Schmähl, D. (1988) No relevant influence on overall survival time in patients with metastatic breast cancer undergoing combination chemotherapy. J. Cancer Res. Clin. Oncol. 114: 183-185.

21. Schmähl, D. \& Berger, M. R. (1988) Possibilities and limitations of antineoplastic chemotherapy: experimental and clinical aspects. Int. J. Exp. Clin. Chemother. 1: 1-11.

22. Unger, C. \& Eibl, H. (1990) Hexadecylphosphocholine: Preclinical and first clinical results of a new antitumor drug. Lipids (in press).

23. Vogler, W. R., Olson, A. C., Okamoto, S., Shoji, M., Kuo, J. F. \& Berdel, W. E. (1989) Comparative effects of lipids on leukemic cell lines and protein kinase C (PKC). Proc. Am. Assoc. Cancer Res. 30: 577.

24. Zeller, W. J. \& Berger, M. R. (1984) Chemically induced autochthonous tumor models in experimental chemotherapy. Behring Inst. Mitt. 74: 201-208. 